\title{
PEMANFAATAN APLIKASI PENYUSUNAN PERENCANAAN PEMBELAJARAN (AP3) DALAM PENYUSUNAN PERENCANAAN PEMBELAJARAN BAGI GURU TAMAN KANAK-KANAK DI JAKARTA
}

\author{
Rohita $^{1^{*}}$, Nila Fitria ${ }^{1}$, Dody Haryadi ${ }^{1}$ \\ ${ }^{1}$ Prodi Pendidikan Anak Usia Dini, Fakultas Psikologi dan Pendidikan, Universitas Al Azhar Indonesia, Jakarta, \\ Indonesia \\ *Penulis Korespondensi: rohita@uai.ac.id
}

\begin{abstract}
Abstrak
Menyusun perencanaan pembelajaran merupakan hal yang mutlak dilakukan guru sebelum melaksanakan pembelajaran, termasuk pembelajaran di Taman Kanak-Kanak (TK). Perencanaan pembelajaran di TK diantaranya adalah Rencana Pelaksanaan Pembelajaran Mingguan (RPPM) dan Rencana Pelaksanaan Pembelajaran Harian (RPPH). Kedua perencanaan tersebut selama ini dilakukan secara manual baik dengan ditulis tangan maupun dengan menggunakan komputer program Ms Word dan Ms Excel, namun dalam prosesnya membutuhkan waktu yang cukup lama. Tujuan dari kegiatan ini adalah untuk meningkatkan kemampuan guru TK dalam menyusun RPPM dan RPPH serta membantu guru TK melakukannya dengan cara yang lebih mudah dan lebih cepat, yaitu dengan menggunakan aplikasi Penyusunan Perencanaan Pembelajaran atau AP3. Kegiatan pengabdian kepada masyarakat ini dilaksanakan di TK yang berlokasi di Kapuk, Cengkareng, Jakarta Barat. Kegiatan dilakukan dalam bentuk pelatihan dan pendampingan pemanfaatan AP3. Kesimpulannya adalah pemanfaatan AP3 dapat meningkatkan kemampuan guru TK dalam menyusun RPPM dan RPPH.
\end{abstract}

Kata kunci: kurikulum 2013, aplikasi penyusunan perencanaan pembelajaran, Taman Kanak-kanak

\begin{abstract}
Preparing lesson planning is an absolute thing done by teachers before implementing learning, including learning in kindergarten. Planning of learning in kindergarten such as Weekly Implementation Plan (RPPM) and Daily Learning Implementation Plan (RPPH). Both of these plans have been done manually either by handwriting or by using the computer program Ms Word and Ms Excel, but in the process takes quite a long time. The purpose of this activity is to improve the kindergarten teacher's ability in covering RPPM and RPPH as well as assisting kindergarten teachers in an easier and faster way, by using the Learning Planning Preparation or AP3 application. Community service activities conducted in kindergarten located in Kapuk, Cengkareng, West Jakarta. Activities undertaken in the form of training and mentoring AP3 utilization. The conclusion is the utilization of AP3 that can improve the kindergarten teacher's ability in covering RPPM and RPPH.
\end{abstract}

Keywords: curriculum 2013, application preparation of learning planning, kindergarten

\section{PENDAHULUAN}

Cengkareng adalah salah satu lokasi yang terletak di wilayah Jakarta Barat dengan kepadatan penduduk yang cukup tinggi. Rumah-rumah berukuran kecil yang terletak di dalam gang serta jalan sempit dan becek ketika hujan, menjadi pemandangan sehari-hari di wilayah tersebut. Taman Kanak-Kanak (TK) Baitul Uyun dan Mutiara Ilmu hadir di tengah-tengah kebutuhan masyarakat dengan jumlah anak usia dini yang cukup banyak, menjadi salah satu solusi dari kebutuhan masyarakat akan pendidikan untuk anak usia dini. TK Baitul Uyun yang berdiri pada tahun 2003 di bawah Yayasan Baitul Uyun beralamat di jalan Kapuk Budi Karya Rt. 018 Rw. 012 No. 70 Kelurahan Kapuk, Kecamatan Cengkarang Jakarta Barat tepatnya di pintu masuk gang Jl. Budi Karya. Sementara itu, di TK Mutiara Ilmu yang berdiri pada tahun 2010, yang berlokasi di jl. Gotong Royong Rt 17 Rw 16, juga memiliki permasalahan yang sama.

TK Mutiara Ilmu saat ini memiliki 30 orang peserta didik yang terbagi menjadi kelompok A sebanyak 8 anak dan kelompok B sebanyak 22 anak. Dengan dibantu dua orang guru, TK Mutiara Ilmu memberikan layanan pendidikan bagi anak usia dini. Latar belakang pendidikan guru di TK Mutiara Ilmu yang bukan berasal dari sarjana menjadi kendala tersendiri bagi kepala TK untuk dapat memberikan layanan PAUD sebagaimana seharusnya. Kesulitan yang dirasakan adalah pada saat ingin mentrasfer ilmu mengenai 
pembuatan rencana pembelajaran sesuai kurikulum 2013. Hal ini berdampak pada tidak dibuatnya Rencana Pelaksanaan Pembelajaran Harian (RPPH) secara tertulis tetapi hanya berdasarkan diskusi dengan kepala TK yang dilakukan setelah kegiatan anak-anak usai.

Adanya tuntutan masyarakat agar anak-anaknya bisa membaca, menulis dan berhitung ketika keluar dari TK dan agar mereka siap memasuki pendidikan di SD, mengakibatkan guru lebih menitikberatkan pendidikan yang diberikan kepada anak pada kegiatan calistung tersebut. Setiap hari, anak distimulasi dengan kegiatankegiatan yang mendukung mereka untuk mampu membaca, menulis dan berhitung. Aspek perkembangan lain tetap diperhatikan, namun dengan porsi yang tidak seimbang.

Berdasarkan analisis situasi yang telah diuraikan, maka dapat diketahui bahwa masalah yang dihadapi mitra 1 dan mitra 2 adalah masalah dalam bidang pendidikan, yaitu dalam hal kurangnya pengetahuan dan pemahaman mengenai tumbuh kembang anak yang berdampak pada pemberian stimulasi kepada anak didiknya melalui kegiatan pembelajaran yang diberikan. Materi pembelajaran yang sama, yang diberikan kepada anak kelompok TK A dan TK B menjadi salah satu dampaknya. Tidak adanya perencanaan, berdampak pada proses penilaian yang seharusnya dilakukan guru terhadap hasil kerja anak.

Sementara dalam bidang kehidupan bermasyarakat, orangtua sangat menginginkan agar anak-anak yang bersekolah di sekolah tersebut pada akhirnya memiliki kemampuan membaca, menulis dan berhitung. Hal tersebut menjadi kendala tersendiri bagi sekolah. Di satu sisi guru cukup memahami kebutuhan anak sesuai aspek perkembangannya, sementara di sisi lain tuntutan orang tua agar anak memiliki kemampuan yang dominan di salah satu aspek (kognitif dan bahasa). Apabila sekolah tidak mampu memenuhi tuntutan tersebut, maka ada kemungkinan sekolah tidak akan mendapatkan murid yang akan bersekolah di tempatnya. Mengingat pentingnya pemahaman akan tumbuh kembang anak serta kemampuan dalam merencanakan kegiatan pembelajaran dalam sebuah proses belajar mengajar maka masalah yang ada perlu untuk segera dicarikan solusinya.

Solusi yang diberikan kepada kelompok masyarakat umum ini adalah berupa transfer ilmu pengetahuan melalui kegiatan pengabdian kepada masyarakat yang didanai dari dana hibah Direktorat Riset dan Pengabdian Masyarakat Kementerian Riset, Teknologi, dan Pendidikan Tinggi (DRPM Kemenristekdikti) pada program Ipteks bagi Masyarakat (IbM). Teknologi yang akan ditransfer pada kegiatan ini diberikan dalam bentuk Aplikasi Penyusunan Perencanaan Pembelajaran (AP3) berbasis kurikulum 2013. Upaya transfer teknologi tersebut dilakukan dengan cara memberikan seminar, workshop serta pendampingan dalam penggunaanya. Seminar diberikan untuk mengetahui tingkat pengetahuan dan pemahaman guru TK mengenai tumbuh kembang anak usia dini serta pemahaman mengenai kurikulum 2013. Workshop diberikan sebagai media sosialisasi aplikasi sekaligus pengenalan langkah-langkah penggunaannya. Sementara pendampingan dilakukan setelah kegiatan workshop diberikan. Hal ini dilakukan agar guru-guru peserta pelatihan dapat menggunakan aplikasi tersebut sesuai dengan langkah-langkah yang dijelaskan dan menghasilkan sebuah rancangan pembelajaran baik dalam bentuk Rancangan Pelaksanaan Pembelajaran Mingguan (RPPM) dan Rancangan Pelaksanaan Pembelajaran Harian (RPPH) yang dilakukan dengan cara yang mudah dan cepat. Kegiatan pendampingan yang dilakukan juga bertujuan untuk mengetahui kendala atau kesulitan yang dihadapi mitra sehingga kendala atau kesulitan tersebut dapat segera diatasi.

Berdasarkan pemaparan tersebut, maka tujuan dari kegiatan pengabdian ini adalah untuk meningkatkan kemampuan guru TK serta memudahkan guru TK dalam menyusun rencana pembelajaran baik rencana pelaksanaan pembelajaran mingguan (RPPM) maupun rencana pelaksanaan pembelajaran harian (RPPH) dengan memanfaatkan Aplikasi Penyusunan Perencanaan Pembelajaran.

\subsection{Pembelajaran di TK}

Pembelajaran pada hakikatnya merupakan proses komunikasi antara peserta didik dengan pendidik serta antar peserta didik dalam rangka perubahan sikap (Suherman dalam Jihad dan Haris, 2008). Sementara Usman (dalam Jihad dan Haris, 2008) menuliskan bahwa pembelajaran merupakan suatu proses yang mengandung serangkaian perbuatan guru dan siswa atas dasar hubungan timbal balik yang berlangsung dalam situasi edukatif untuk mencapai tujuan tertentu. Di dalam proses pembelajaran, baik guru maupun suswa bersama-sama menjadi pelaku terlaksananya tujuan pembelajaran. Tujuan pembelajaran akan mencapai hasil yang maksimal apabila pembelajaran berjalan efektif. Wragg dalam Jihad dan Haris (2008) mengatakan bahwa pembelajaran yang efektif adalah pembelajaran yang memudahkan siswa untuk mempelajari sesuatu yang bermanfaat seperti fakta, ketrampilan, nilai, konsep, dan bagaimana hidup serasi dengan sesama, atau suatu hasil belajar yang diinginkan.

Pembelajaran perlu direncanakan dan dirancang secara optimal agar dapat memenuhi harapan dan tujuan. Jihad dan Haris (2008) menuliskan bahwa Rancangan pembelajaran hendaknya memperhatikan: 1 . Pembelajaran diselenggarakan dengan pengalaman nyata dan lingkungan otentik; 2 . Isi pembelajaran harus didesain agar relevan dengan karakteristik siswa; 3 . Menyediakan media dan sumber belaajr yang dibutuhkan, dan 4. Penilaian hasil belajar terhadap siswa dilakukan secara formatif sebagai diagnosis untuk menyediakan pengalaman belajar secara 
berkesinambungan dan dalam bingkai belajar sepanjang hayat

Pembelajaran di TK saat ini menggunakan model pembelajaran tematik. Pembelajaran tematik merupakan pembelajaran terpadu yang menggunakan tema untuk mengaitkan beberapa mata pelajaran/ aspek perkembangan sehingga dapat memberikan pengalaman bermakna kepada siswa. Tema adalah pokok pikiran atau gagasan pokok yang menjadi pokok pembicaraan. (Poerwadarminta dalam Jihad dan Haris, 2008). Adapun ciri-ciri pembelajaran tematik antara lain: 1. Pengalaman dan kegiatan belajar sangat relevan dengan tingkat perkembangan dan kebutuhan anak usia dini; 2. Kegiatan-kegiatan yang dipilih dalam pelaksanaan pembelajaran tematik bertolak dari minat dan kebutuhan siswa; 3. Kegiatan belajar akan lebih bermakna dan berkesan bagi siswa sehingga hasil belajar dapat bertahan lebih lama; 4. Membantu mengembangkan ketrampilan berpikir siswa; 5 . Menyajikan kegiatan belajar yang bersifat pragmatis sesuai dengan permasalah yang sering ditemui siswa dalam lingkungannya; dan 6. Mengembangkan ketrampilan sosial siswa, seperti kerjasama, toleransi, komunikasi, dan tanggap terhadap gagasan orang lain.

Kegiatan belajar yang diberikan pada anak usia TK harus memperhatikan prinsip-prinsip pembelajarannya, yaitu: 1 . bermain sambil belajar atau belajar seraya bermain; 2 . berorientasi pada kebutuhan anak; 3. stimulasi terpadu; 4. berorientasi pada perkembangan anak; 5. lingkungan kondusif; 6 . menggunakan pendekatan tematik; 7. pembelajaran aktif, kreatif, efektif dan menyenangkan (PAKEM); dan 8. menggunakan berbagai media dan sumber belajar

Kedelapan prinsip pembelajaran tersebut harus dapat dilaksanakan oleh pendidik anak usia dini. Selain itu, di dalam memberikan stimulasi, pendidik juga harus memahami dan menguasai tingkat capaian perkembangan seperti yang tertera pada kurikulum 2013. Dengan demikian pembelajaran yang diberikan kepada anak usia dini dapat dikatakan sesuai dengan tingkat usia, tingkat perkembangan dan sesuai pula dengan kebutuhan anak usia dini sehingga diharapkan berbagai stimulasi yang diberikan tersebut dapat meningkatkan berbagai potensi yang ada pada setiap anak.

Di dalam prosesnya, pembelajaran di TK dapat menggunakan bermacam-macam metode. Di dalam buku Metode Pengajaran di Taman Kanak-kanak, Moeslichatoen (19990, menuliskan bahwa metode merupakan cara yang dalam bekerjanya merupakan alat untuk mencapai tujuan kegiatan. Lebih lanjut beliau menuliskan bahwa terdapat metode pengajaran yang sesuai dengan karakteristik anak usia TK, yaitu: Metode Bercerita; Metode Bercakap-cakap; Metode Tanya Jawab; Metode Karya Wisata; Metode Demonstrasi; Metode Sosiodrama dan Bermain Peran;
Metode Eksperimen; Metode Proyek; Metode Pemberian Tugas; dan Metode Bermain. Adanya metode-metode tersebut tentu memudahkan guru TK dalam upaya menyampaikan materi yang telah ditentukan sebelumnya. Hal ini juga tentu akan menarik minat anak dalam belajar karena adanya variasi cara mengajar melalui berbagai metode yang dipilih sesuai dengan karakteristik anak TK.

\subsection{Perencanaan Pembelajaran}

Sementara Terry dalam Majid (2007) menyatakan bahwa perencanaan adalah menetapkan pekerjaan yang harus dilaksanakan oleh kelompok untuk mencapai tujuan yang digariskan. Lebih lanjut Terry menyatakan bahwa mengingat perencanaan berisi kegiatan pengambilan keputusan, diperlukan kemampuan untuk mengadakan visualisasi dan melihat ke depan guna merumuskan suatu pola tindakan untuk masa depan.

Menurut Permendikbud No 81A tahun 2013 tentang implementasi Kurikulum Pedoman Umum Pembelajaran, bahwa tahap pertama dalam pembelajaran menurut standar proses yaitu perencanaan pembelajaran yang diwujudkan dengan kegiatan penyusunan Rencana Pelaksanaan Pembelajaran (RPP). Adapun yang dimaksud dengan RPP adalah rencana pembelajaran yang dikembangkan secara rinci dari suatu materi pokok atau tema tertentu yang mengacu pada silabus. Di dalam buku Penyusunan Rencana Pelaksanaan Pembelajaran Pendidikan Anak Usia Dini yang dikeluarkan Direktorat Jenderal Pendidikan Anak Usia Dini dan Pendidikan Masyarakat (2015) dituliskan bahwa yang dimaksud dengan rencana pelaksanaan pembelajaran merupakan rancangan bagi guru untuk melaksanakan kegiatan bermain yang memfasilitasi anak dalam proses belajar. Rencana pelaksanaan pembelajaran harus dibuat sebelum kegiatan pembelajaran dilaksanakan. Rencana pembelajaran harus mengacu kepada karakteristik (usia, sosial budaya, dan kebutuhan individual) anak. Adapun hal-hal yang harus diperhatikan dalam menyusun rencana pelaksanaan pembelajaran adalah:

a) Memahami Standar Tingkat Pencapaian Perkembangan Anak (STPPA) sebagai hasil akhir program PAUD (Kompetensi Inti)

b) Memahami kompetensi dasar sebagai capaian hasil pembelajaran

c) Menetapkan materi pembelajaran sebagai muatan untuk pengayaan pengalaman anak

Berkaitan dengan tugas guru, terdapat tiga jenis perencanaan pembelajaran yang harus disusun dan disiapkan oleh guru sebelum melaksanakan pembelajaran, yaitu: Program Semester (Prosem), Rencana Pelaksanaan Pembelajaran Mingguan (RPPM), dan Rencana Pelaksanaan Pembelajaran Harian (RPPH). Ketiga perencanaan tersebut harus dapat dilaksanakan dengan tepat sesuai dengan kebutuhan dan karakteristik anak TK. 


\subsection{Teknologi Informasi}

Suatu pendidikan tidak akan berkembang atau berjalan tanpa adanya beberapa faktor pendukung. Salah satu faktor pendukung tersebut adalah dengan adanya Teknologi Informasi. Teknologi Informasi (TI) adalah suatu teknologi yang digunakan untuk menglah data, termasuk memproses, mendapatkan, menyusun, menyimpan, memanipulasi data dalam berbagai cara untuk menghasilka informasi yang berkualitas, yaitu informasi yang relevan, akurat dan tepat waktu yang digunakan untuk keperluan pribadi, bisnis, pemerintahan dan merupakan informasi strategis untuk pengambilan keputusan. (Martin dalam Cahyana, 2015). Penerapan Teknologi Informasi dapat menyebabkan perubahan pada kebiasaan kerja. Sementara Eltson (dalam Ramdhan, 2012) menuliskan bahwa Teknologi Informasi (Information Technology) "as the technology used to manage information".

Terdapat enam fungsi teknologi informasi (Cahyana, 2015), yaitu:

a) Menangkap (capture), diartikan sebagai menginput

b) Mengolah (processing), disebut juga memproses data, yaitu memproses data masukkan yang diterima untuk menjadi informasi

c) Menghasilkan (generating), atau mengorganisasikan informasi ke dalam bentuk yang berguna atau laporan yang dapat dimengerti oleh orang lain

d) Menyimpan (storage), yaitu merekam atau menyimpan data dan informasi dalam suatu media yang dapat digunakan untuk keperluan lain

e) Mencari kembali (retrival), yaitu menelusuri dan mendapatkan kembali informasi atau mengkopi data dan informasi yang sudah tersimpan.

f) Mentransmisi (transmission), yaitu mengirim data dan informasi dari suatu lokasi ke lokasi lain melalui jaringan komputer.

\section{BAHAN DAN METODE}

Bahan utama yang digunakan dalam kegiatan pengabdian kepada masyarakat ini adalah kurikulum 2013 yang terdapat dalam buku Peraturan Menteri Pendidikan dan Kebudayaan Republik Indonesia (Permendikbud RI) No. 146 dan No. 137 Tahun 2014 serta Aplikasi Penyusunan Perencanaan Pembelajaran yang telah dibuatkan user dan password untuk guru TK peserta kegiatan pengabdian kepada masyarakat.

Metode pelaksanaan yang digunakan pada kegiatan pengabdian kepada masyarakat ini adalah bentuk seminar, workshop dan pendampingan. Seminar diberikan dengan materi mengenai tumbuh kembang anak dan kurikulum 2013. Hal tersebut bertujuan untuk mengetahui tingkat pengetahuan dan pemahaman guru TK terkait materi yang diberikan tersebut sehingga akan memudahkan guru-guru dalam membuat perencanaan pembelajaran. Workshop dilakukan terkait pengenalan AP3 sekaligus penjelasan langkahlangkah penggunaan AP3. Sementara pendampingan yang dilakukan bertujuan agar dapat digunakan sebagai bentuk evaluasi keberhasilan kegiatan pengabdian kepada masyarakat.

\section{HASIL DAN PEMBAHASAN \\ 3.1 Hasil Kegiatan}

1) Seminar Tentang Tumbuh Kembang AUD Dan Kurikulum 2013

Kegiatan seminar dilaksanakan pada Jumat, 11 Agustus 2017 dengan materi mengenai tumbuh kembang anak usia dini dan kurikulum 2013. Kegiatan seminar dimulai pada pukul 09.30 WIB yang diawali dengan pemberian angket oleh Ibu Nila Fitria, M.Pd. Pada hari itu pula dilaksanakan seminar parenting bagi orangtua murid mengenai tumbuh kembang anak usia dini dengan judul Pembelajaran Calistung dan Dampaknya bagi Tumbuh Kembang Anak Usia Dini. Kegiatan dilaksanakan mulai pukul 09.00-12.00 WIB.

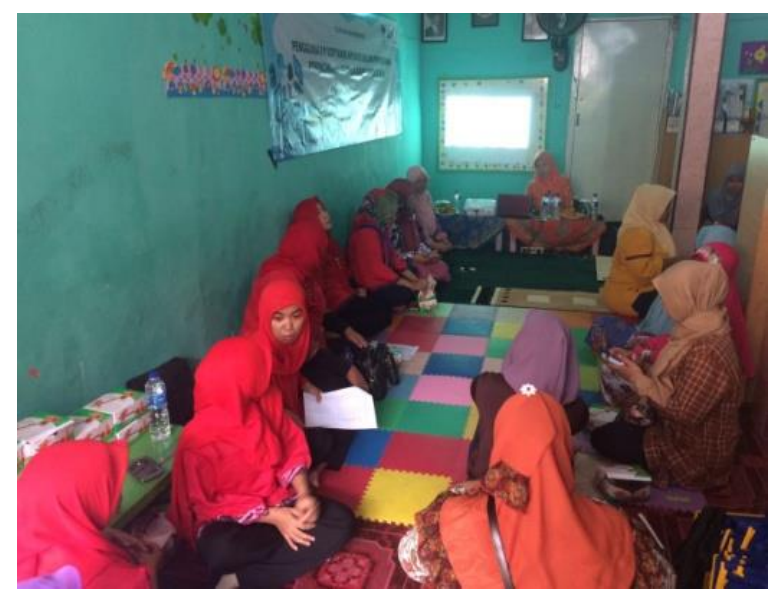

Gambar 1. Kegiatan Pelatihan Tumbuh Kembang dan Kurikulum 2013

Berdasarkan hasil angket, diketahui bahwa materi tumbuh kembang anak dirasakan bermanfaat bagi guru-guru TK karena menambah wawasan tentang perkembangan anak serta mengetahui masa peka belajarnya. Hal tersebut juga berguna bagi guru untuk dapat menangani anak dan sifat-sifat anak. Terkait dengan pengetahuan guru akan kurikulum 2013, diperoleh informasi yang disajikan dalam bentuk diagram berikut. 


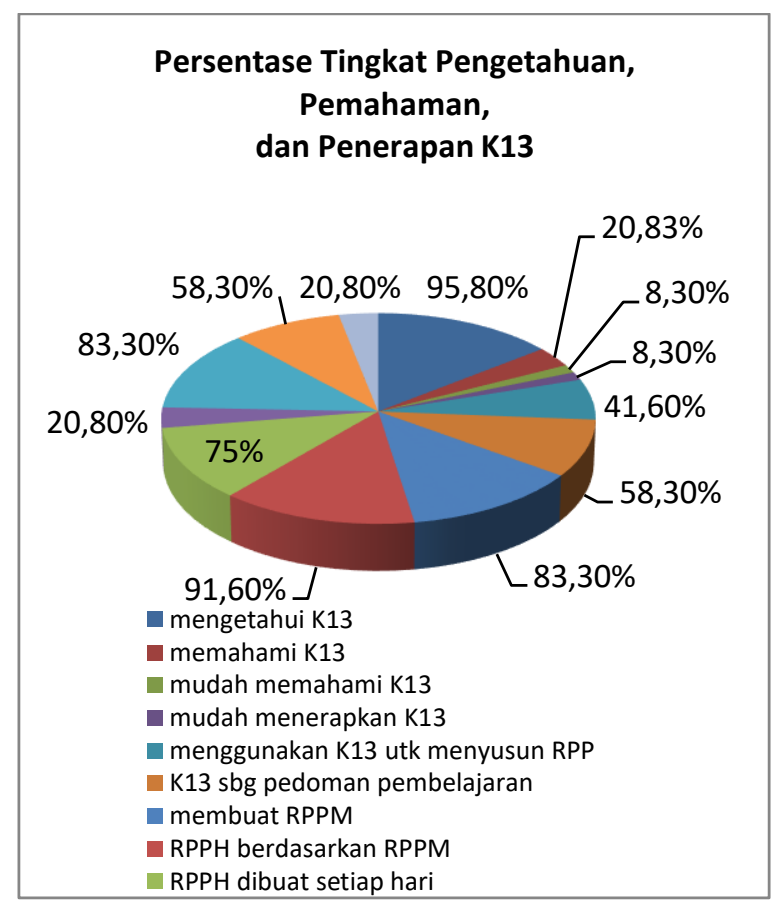

Diagram 1. Tingkat Pengetahuan, Pemahaman dan Penerapan Kurikulum 2013

Berdasarkan grafik di atas dapat diketahui bahwa tingkat pengetahuan guru mengenai kurikulum 2013 sangat tinggi namun belum diikuti dengan tingkat pemahaman dan tingkat kemampuan menerapkan kurikulum 2013 dalam penyusunan perencanaan pembelajaran. Selain itu penyusunan RPPH dilakukan kebanyakan guru dengan cara tulis tangan.

\section{2) Seminar Parenting "Pembelajaran Calistung Dan Dampaknya Bagi Tumbuh Kembang AUD"} Kegiatan seminar Parenting dilakukan bersamaan dengan kegiatan seminar Tumbuh Kembang AUD dan Kurikulum 2013. Kegiatan ini diawali dengan memberikan lembar pre tes untuk mengetahui pengetahuan dan pemahaman orangtua mengenai tumbuh kembang anak serta cara menstimulasi anak terkait dengan pembelajaran baca, tulis, dan hitung (calistung). Tepat pukul 10.00 kegiatan dilanjutkan dengan pemberian materi oleh ibu Rohita, M.Pd. Dari pertanyaan dan jawaban yang diberikan peserta sejumlah 17 orang, diketahui bahwa sebagian besar pernah melakukan kekerasan fisik maupun verbal pada saat menstimulasi anak untuk bisa melakukan calistung serta memiliki kekhawatiran akan ketidakmampuan calistung anak saat anak masuk SD.

Kegiatan parenting selesai pukul 11.30 WIB yang dilanjutkan dengan pengisian pos tes untuk mengetahui adakah perubahan pengetahuan dan pemahaman orangtua mengenai tumbuh kembang anak dan cara menstimulasi anak terkait calistung. Kegiatan ini selesai pukul 12.00 WIB yang diakhiri dengan foto bersama peserta.

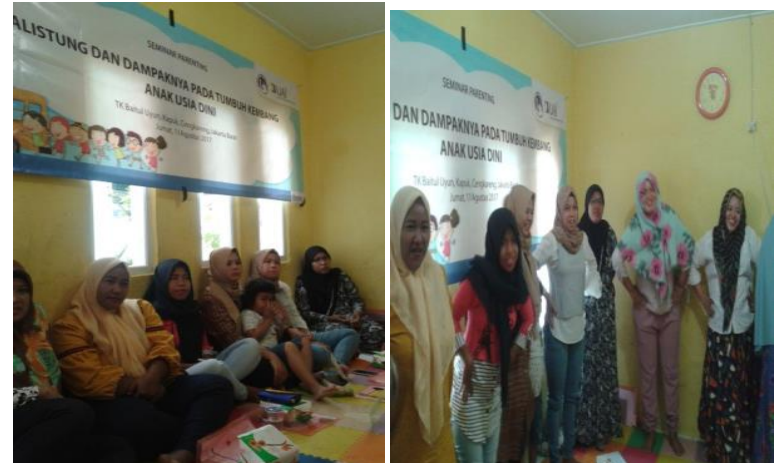

Gambar 2. Peserta Seminar Parenting

Berikut disajikan grafik hasil pre dan pos tes kegiatan seminar parenting mengenai Pembelajaran Calistung dan Dampaknya bagi Tumbuh Kembang Anak Usia Dini.

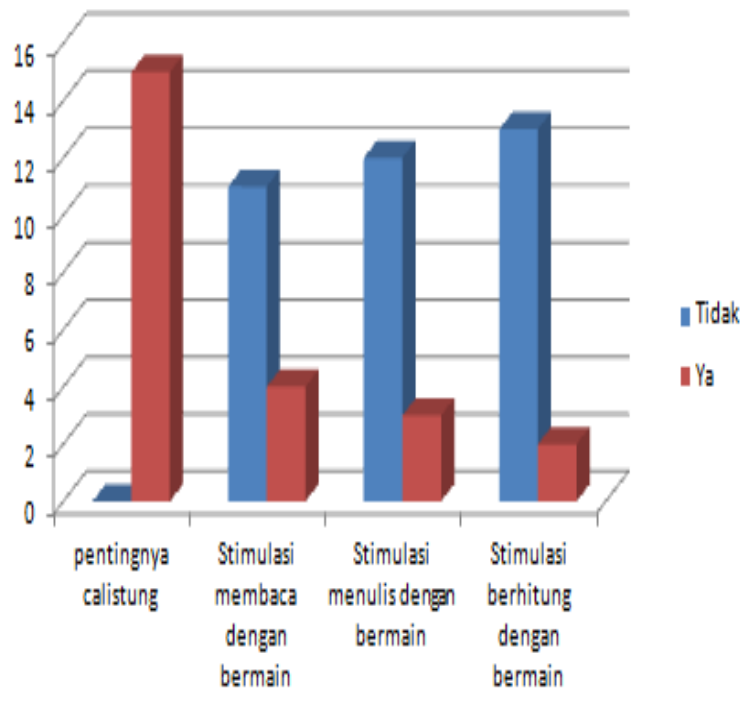

Grafik 1. Hasil Pre Tes

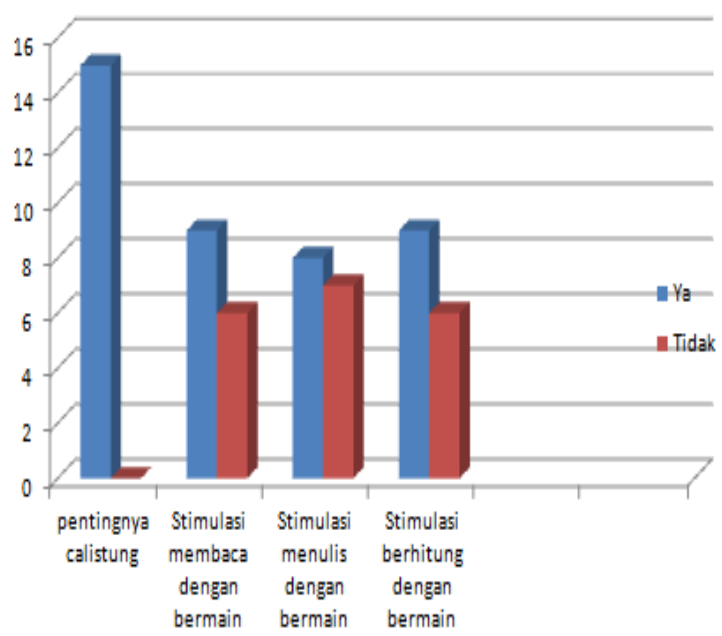

Grafik 2. Hasil Post Tes

Berdasarkan dua grafik di atas, grafik 1 dan grafik 2, dapat dilihat adanya perubahan pengetahuan dan 
pemahaman orang tua mengenai cara menstimulasi anak terkait pembelajaran membaca, menulis, dan berhitung atau yang lebih dikenal dengan istilah calistung. Dapat disampaikan bahwa setelah mengikuti seminar parenting, orangtua menyatakan akan menstimulasi kemampuan calistung anak dengan cara bermain.

\section{3) Workshop}

Pada hari kedua, Sabtu, 12 Agustus 2017, dilaksanakan workshop dengan judul Penggunaan Aplikasi Dalam Penyusunan Perencanaan Pembelajaran Berbasis K13. Workshop dilakukan untuk secara langsung mengenalkan dan melatih guru-guru TK untuk dapat memanfaatkan aplikasi tersebut dalam menyusun perencanaan pembelajaran dengan mudah. Melalui kegiatan workshop ini pula, guru-guru TK diajarkan tahap demi tahap penyusunan rencana pembelajaran dengan menggunakan aplikasi yang ada.

Kegiatan workshop disampaikan oleh bapak Dody Hariyadi, ST., M.Ti terkait materi penyusunan RPPM dan RPPH menggunakan aplikasi yang telah disediakan. Aplikasi Penyusunan Perencanaan Pembelajaran merupakan Ipteks yang dirancang untuk ditransferkan kepada guru-guru TK sebagai inti dari kegiatan pengabdian kepada masyarakat ini.

Workshop diawali dengan pengenalan aplikasi sehingga peserta mengetahui dan memahami aplikasi yang akan digunakan pada hari ini. Kegiatan dilanjutkan dengan praktek penyusunan RPPM dan RPPH menggunakan aplikasi yang diberikan. Ibu Nila Fitria, M.Pd. dan ibu Rohita, M.Pd. bertindak selaku pendamping yang bertugas membantu peserta mengikuti tahap demi tahap penyusunan RPPM dan RPPH menggunakan aplikasi yang ada. Di dalam workshop, pemateri mengenalkan mengenai aplikasi yang akan digunakan serta langkah-langkah yang harus dilakukan hingga dapat tersusun sebuah perencanaan pembelajaran yang terdiri dari RPPM dan RPPH. Berikut adalah tampilan AP3 yang diberikan kepada guru-guru TK peserta kegiatan pengabdian kepada masyarakat.

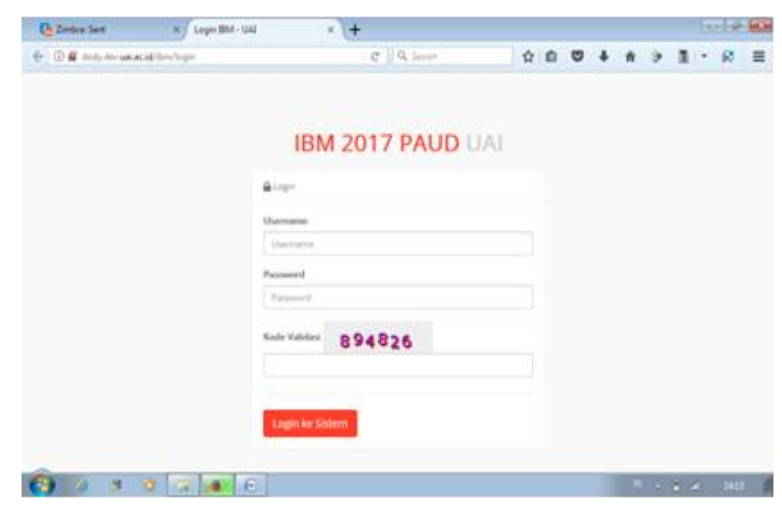

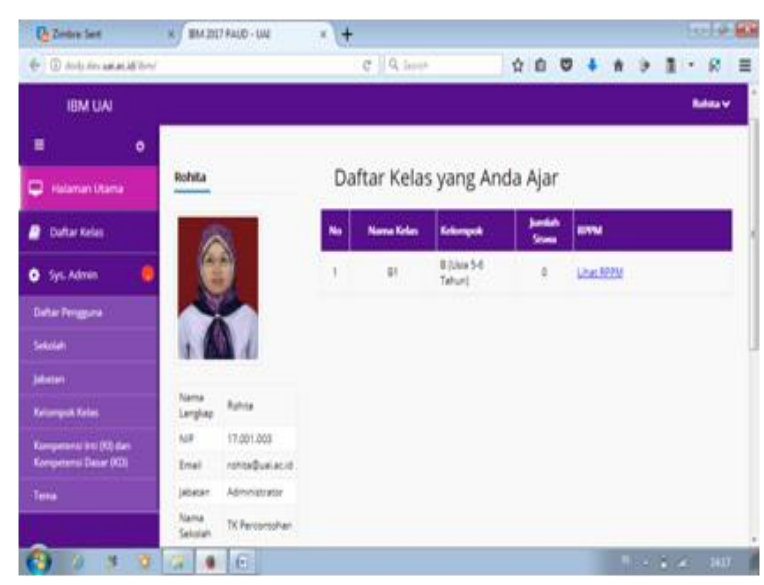

Gambar 4. Halaman Utama Aplikasi

Format isian yang terdapat di dalam aplikasi merupakan format penyusunan perencanaan pembelajaran yang diambil sesuai dengan format yang tersedia dalam buku Penyusunan Rencana Pelaksanaan Pembelajaran Pendidikan Anak Usia Dini. Kementerian Pendidikan dan Kebudayaan Direktorat Jenderal Pendidikan Anak Usia Dini dan Pendidikan Masyarakat Direktorat Pembinaan Pendidikan Anak Usia Dini (2015).

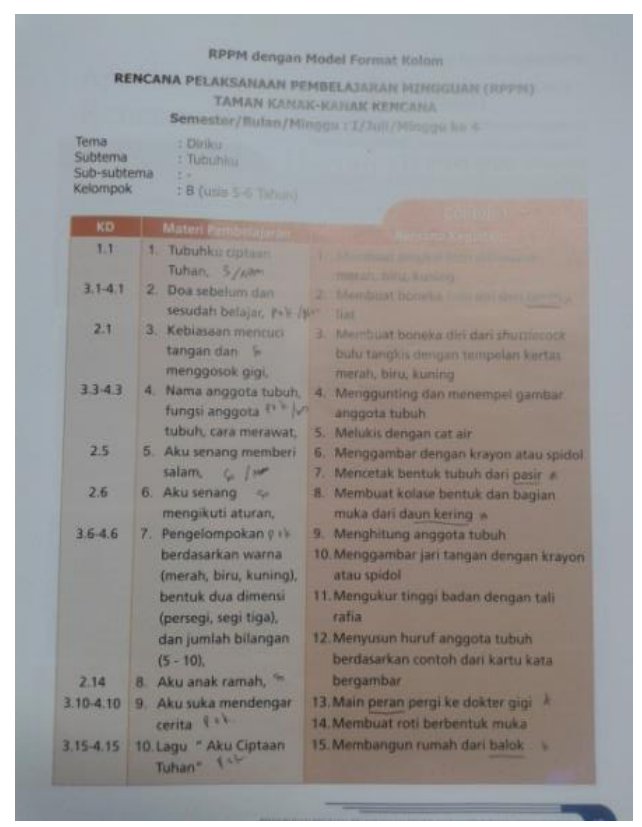

Gambar 5. Contoh RPPM dalam Buku Panduan

Gambar 3. Tampilan Awal Aplikasi 


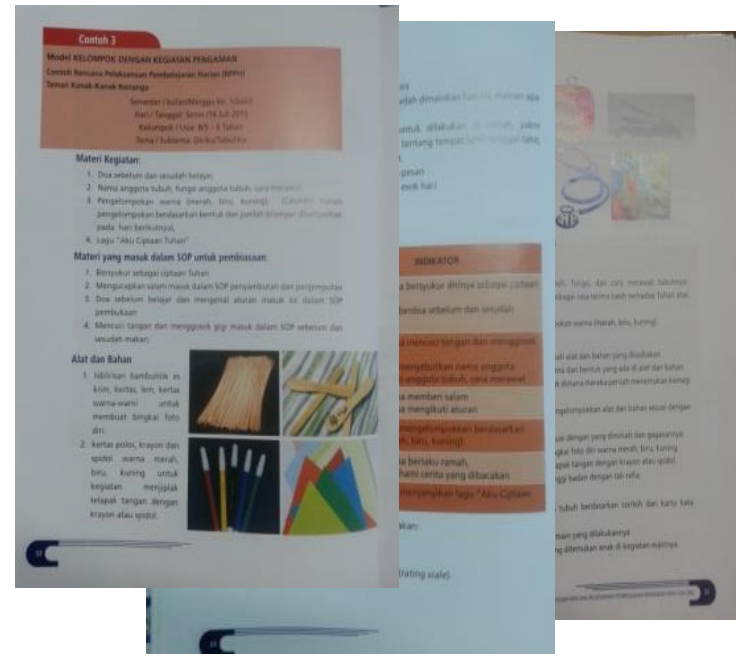

Gambar 6. Contoh RPPH dalam Buku Panduan

Selain itu, pemateri juga menyampaikan bahwa konten pengisian RPPM dan RPPH diambil dari kurikulum yang berlaku saat ini, yaitu kurikulum PAUD 2013 yang terdapat dalam Peraturan Menteri Pendidikan dan Kebudayaan Republik Indonesia (Permendikbud RI) No. 146 dan No. 137 Tahun 2014. Di dalam kurikulum 2013 tersebut, dengan jelas dituliskan mengenai lingkup perkembangan yang meliputi Nilai Agama dan Moral, Fisik Motorik, Bahasa, Kognitif, Sosial Emosional dan Seni. Di dalam kurikulum 2013 tersebut juga dicantumkan Tingkat Pencapaian Perkembangan Anak termasuk kelompok usia 4-6 tahun (usia Taman Kanak-kanak). Berikut adalah konten kurikulum 2013 yang akan diisikan dalam AP3.

Tabel 1. Kurikulum 2013

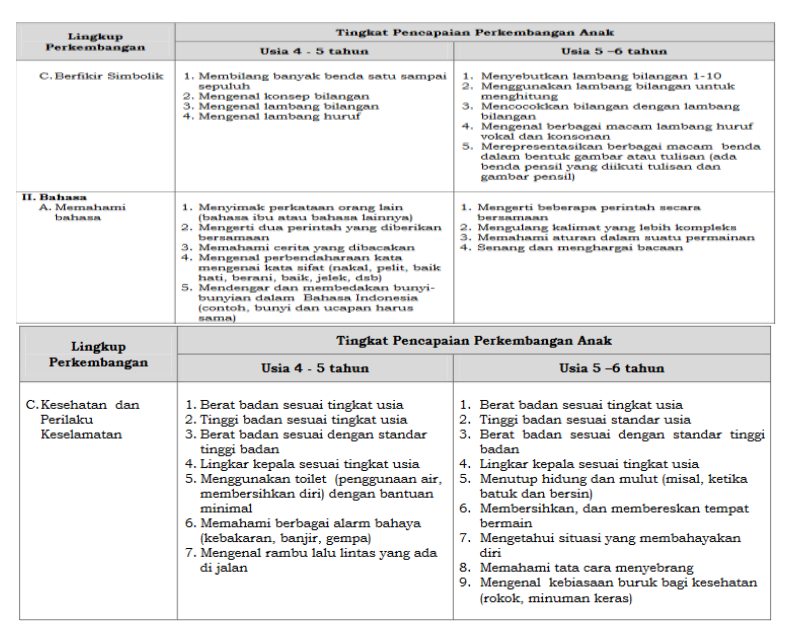

\begin{tabular}{|c|c|c|}
\hline \multirow{2}{*}{$\begin{array}{c}\text { Lingkup } \\
\text { Perkembangan }\end{array}$} & \multicolumn{2}{|c|}{ Tingkat Pencapaian Perkembangan Anak } \\
\hline & Usia 4 - 5 tahun & Usia $5-6$ tahun \\
\hline $\begin{array}{l}\text { I. Nilai Agama dan } \\
\text { Moral }\end{array}$ & $\begin{array}{l}\text { 1. Mengetahui agama yang dianutnya } \\
\text { 2. Meniru gerakan beribadah dengan } \\
\text { urutan yang benar } \\
\text { 3. Mengucapkan doa sebelum dan/atau } \\
\text { sesudah melalukaka sesuatu } \\
\text { 4. Mengenal perilaku baik/sopan dan } \\
\text { buruk } \\
\text { 5. Membiasakan diri berperilaku baik } \\
\text { 6. Mengucapkan salam dan membalas } \\
\text { salam }\end{array}$ & $\begin{array}{l}\text { 1. Mengenal agama yang dianut } \\
\text { 2. Mengerjakan ibadah } \\
\text { 3. Berperilaku jujur, penolong, sopan, hormat, } \\
\text { sportif, dsb } \\
\text { 4. Menjaga kebersihan diri dan lingkungan } \\
\text { 5. Mengetahui hari besar agama } \\
\text { 6. Menghormati (toleransi) agama orang lain }\end{array}$ \\
\hline $\begin{array}{l}\text { II. Fisik-motorik } \\
\text { A. Motorik Kasar }\end{array}$ & $\begin{array}{l}\text { 1. Menirukan gerakan binatang, pohon } \\
\text { tertiup angin, pesawat terbang, dsb } \\
\text { 2. Melakukan gerakan menggantung } \\
\text { (bergelayut) } \\
\text { 3. Melakkukan gerakan melompat, } \\
\text { meloncat, dan berlari secara } \\
\text { terkoordinasi } \\
\text { 4. Melempar sesuatu secara terarah } \\
\text { 5. Menangkap sesuatu secara tepat } \\
\text { 6. Melakkukan gerakan antisipasi } \\
\text { 7. Menendang sesuatu secara terarah } \\
\text { 8. Memanfaatkan alat permainan di luar } \\
\text { kelas }\end{array}$ & $\begin{array}{l}\text { 1. Melakukan gerakan tubuh secara } \\
\text { terkoordinasi untuk melatih kelenturan, } \\
\text { keseimbangan, dan kelincahan } \\
\text { 2. Melakukan koordinasi gerakan mata-kaki- } \\
\text { tangan-kepala dalam menirukan tarian atau } \\
\text { senam } \\
\text { 3. Melakukan permainan fisik dengan aturan } \\
\text { 4. Terampil menggunakan tangan kanan dan } \\
\text { kiri } \\
\text { 5. Melakukan kegiatan kebersihan diri }\end{array}$ \\
\hline Lingkup & \multicolumn{2}{|c|}{ Tingkat Pencapaian Perkembangan Anak } \\
\hline Perkembangan & Usia 4 - 5 tahun & Usia 5 -6 tahun \\
\hline B. Motorik Halus & $\begin{array}{l}\text { 1. Membuat garis vertikal, horizontal, } \\
\text { lengkung kiri/kanan, miring } \\
\text { kiri/kanan, dan lingkaran } \\
\text { 2. Menjiplak bentuk } \\
\text { 3. Mengkoordinasikan mata dan tangan } \\
\text { untuk melakukan gerakan yang rumit } \\
\text { 4. Melakukan gerakan manipulatif } \\
\text { untuk menghasilkan suatu bentuk } \\
\text { dengan menggunakan berbagai media } \\
\text { 5. Mengekspresikan diri dengan } \\
\text { berkarya seni menggunakan berbagai } \\
\text { media } \\
\text { 6. Mengontrol gerakan tangan yang } \\
\text { meggunakan otot halus (menjumput, } \\
\text { mengelus, mencolek, mengepal, } \\
\text { memelintir, memilin, memeras) }\end{array}$ & $\begin{array}{l}\text { 1. Menggambar sesuai gagasannya } \\
\text { 2. Meniru bentuk } \\
\text { 3. Melakukan eksplorasi dengan berbagai } \\
\text { media dan kegiatan } \\
\text { 4. Menggunakan alat tulis dan alat makan } \\
\text { dengan benar } \\
\text { 5. Menggunting sesuai dengan pola } \\
\text { 6. Menempel gambar dengan tepat } \\
\text { 7. Mengekspresikan diri melalui gerakan } \\
\text { menggambar secara rinci }\end{array}$ \\
\hline Lingkup & \multicolumn{2}{|c|}{ Tingkat Pencapaian Perkembangan Anak } \\
\hline Perkembangan & Usia 4 - 5 tahun & Usia 5-6 tahun \\
\hline $\begin{array}{l}\text { IV. Kognitif } \\
\text { A. Belajar dan } \\
\text { Pemecahan } \\
\text { Masalah } \\
\text { Masah }\end{array}$ & 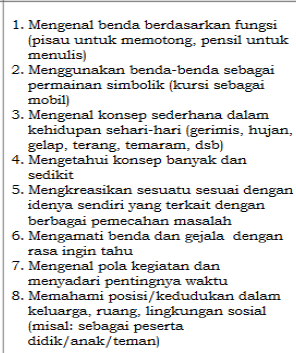 & 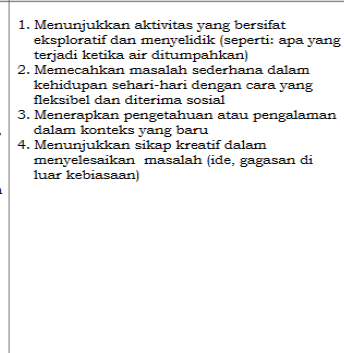 \\
\hline \multirow{2}{*}{$\begin{array}{c}\text { Lingkup } \\
\text { Perkembangan }\end{array}$} & \multicolumn{2}{|c|}{ Tingkat Pencapaian Perkembangan Anak } \\
\hline & Usia 4 - 5 tahun & Usia $5-6$ tahun \\
\hline B. Berfikir Logis & 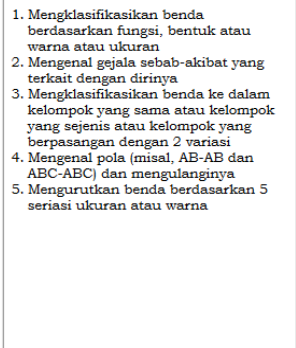 & 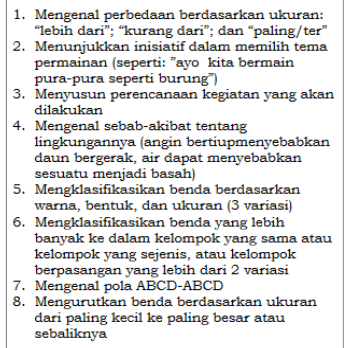 \\
\hline
\end{tabular}




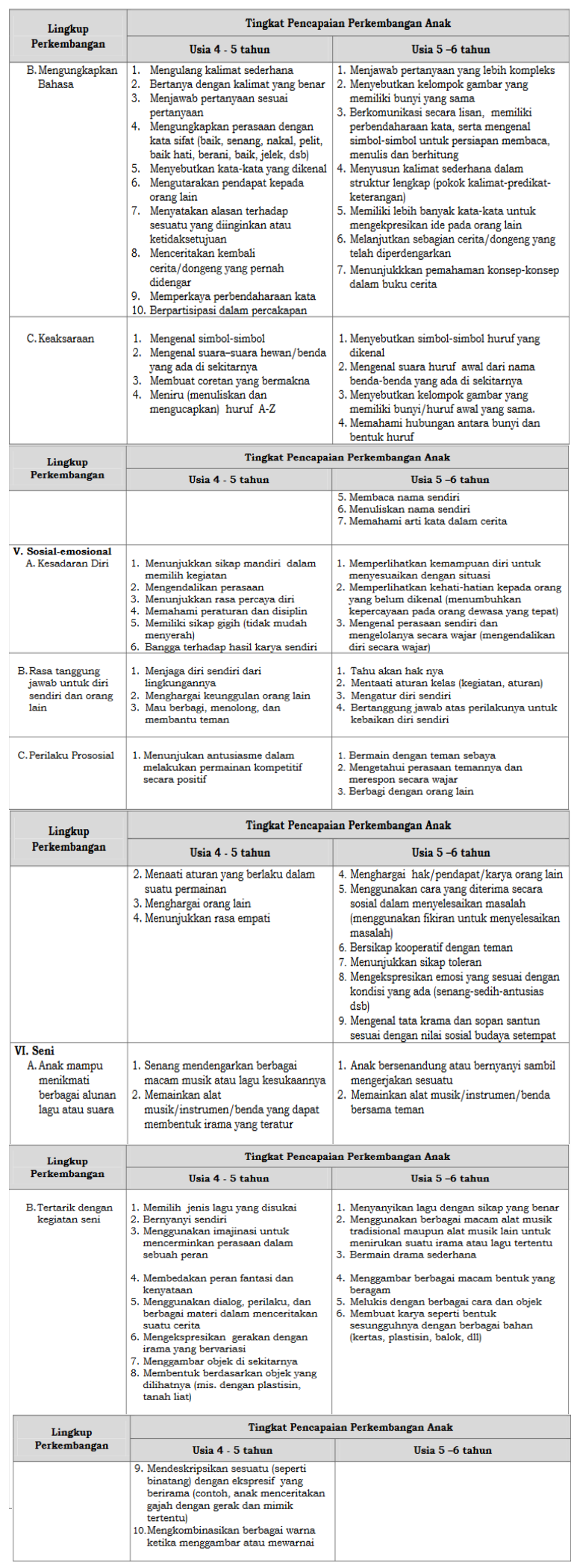

MENTERI PENDIDIKAN DAN KEBUDAYAAN REPUBLIK INDONESIA,
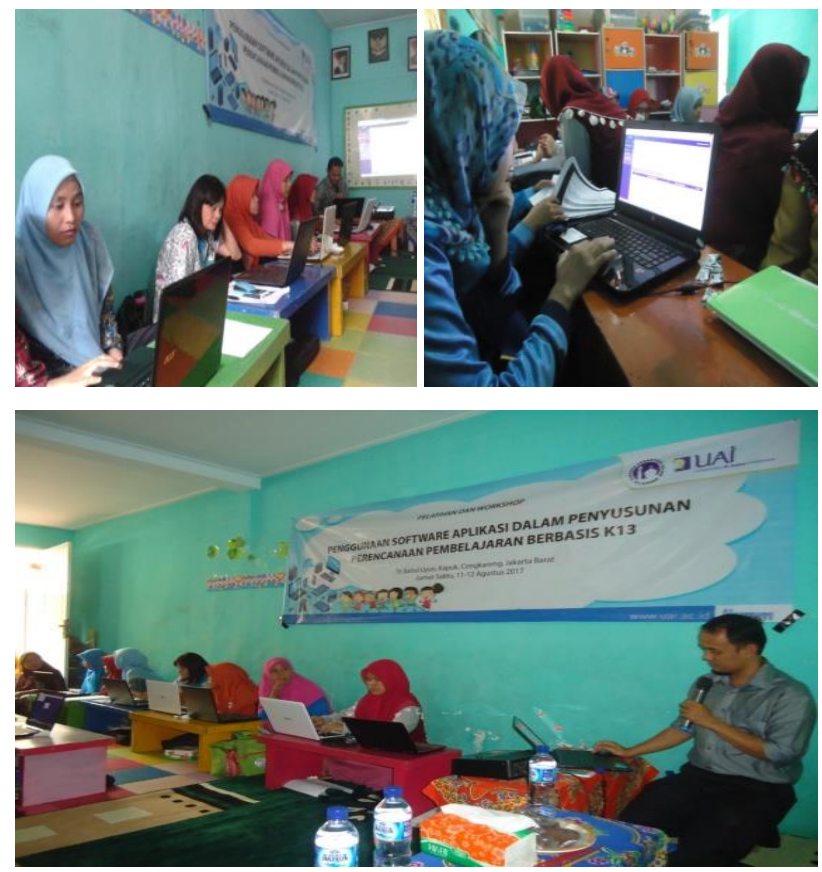

Gambar 7. Workshop Pemanfaatan Aplikasi

Kegiatan workshop penyusunan RPPM dan RPPH menggunakan aplikasi berakhir pukul 12.00WIB, yang diakhiri dengan sesi foto bersama tim pelaksana pengabdian kepada masyarakat, Mitra 1, Mitra 2 serta guru-guru TK peserta seminar dan workshop.

Di dalam proses penyusunan RPPM dan RPPH menggunakan aplikasi terjadi kendala-kendala yaitu:

a) akses internet yang lambat berakibat pada sulit terbukanya laman yang dituju

b) akun pengguna aplikasi yang disediakan setiap sekolah hanya satu, sedangkan perwakilan sekolah lebih dari satu mengakibatkan trouble dalam penggunaan aplikasi

c) sebagian besar peserta tidak membawa RPPM dan RPPH yang mengakibatkan peserta harus memikirkan kembali data yang akan diinput dalam kolom RPPM dan RPPH pada aplikasi

d) sebagian guru belum sepenuhnya memahami kurikulum 2013 sehingga menghambat penyusunan RPPM dan RPPH dalam menentukan Kompetensi Inti dan Kompetensi Dasar.

\section{4) Pendampingan}

Kendala yang dialami guru-guru TK dalam memanfaatkan AP3 yang terjadi saat workshop, ditindaklanjuti dengan melakukan kegiatan pendampingan. Kegiatan pendampingan, dilakukan selama bulan Agustus hingga September dalam bentuk komunikasi via Whatsapp dan telpon. Whatsapp dilakukan pada $3,9,12,13,14,15$, dan 19 Oktober, sementara pendampingan via telpon dilakukan pada tanggal 21 Agustus, 13 Oktober, dan 15 Oktober. Pembicaraan yang dilakukan via Whatsapp seputar progres penyusunan RPPM dan RPPH dengan menggunakan AP3 serta masalah-masalah yang 
mungkin menjadi kendala dalam proses penyelesaiannya.

Kunjungan juga dilakukan pada Kamis, 12 Oktober 2017, bertempat di TK Mutiara Ilmu, Kapuk, Cengkareng, Jakarta Barat. Berdasarkan hasil kunjungan dapat disampaikan bahwa pendampingan penyusunan RPPM dan RPPH yang dilakukan pada hari itu mengalami kendala. Hal tersebut dikarenakan lokasi TK Mutiara Ilmu sebagai mitra 2 yang sangat berdekatan dengan menara sutet mengakibatkan akses internet yang sulit diperoleh. Lamanya proses akses internet membutuhkan cukup banyak waktu sehingga proses penyusunan perencanaan pembelajaran tidak berjalan sebagaimana yang diharapkan.

Hal lain yang dilakukan saat pendampingan adalah penjelasan kembali tahapan-tahapan dalam menggunakan aplikasi. Kegiatan pendampingan selesai pukul 13.00 WIB, dimana mitra 1 dan mitra 2 telah mencoba menyusun rencana pembelajara mingguan (RPPM) dan rencana pembelajaran harian (RPPH) menggunakan software aplikasi yang diberikan. Kegiatan penyusunan RPPM dan RPPH dilanjutkan kembali di TK masing-masing, karena waktu yang tidak memungkinkan untuk melanjutkan kegiatan.

Hasil dari pendampingan adalah mitra 1 telah mencoba mengisi rencana pelaksanaan pembelajaran mulai dari mengisikan satu tema yaitu tema "binatang" dengan sub tema "binatang piaraan", yang kemudian dilanjutkan dengan mencoba menyusun RPPM. Sedangkan mitra 2 telah mencoba menyusun rencana pembelajaran hingga sampai rencana harian.Kegiatan terakhir yang dilakukan saat pendampingan adalah meminta validasi kepada mitra 1 dan mitra 2 yang sekaligus sebagai user utama aplikasi ini.

Berikut adalah contoh hasil penyusunan RPPM dan RPPH guru TK dengan menggunakan AP3.

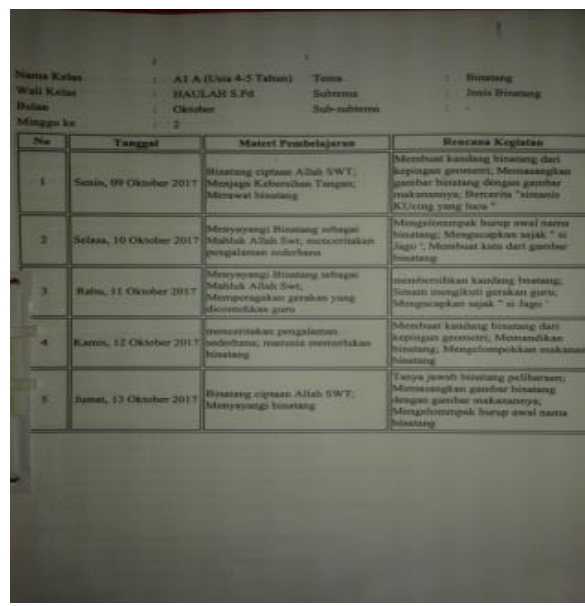

Gambar 8. Benttuk RPPM Menggunakan AP3
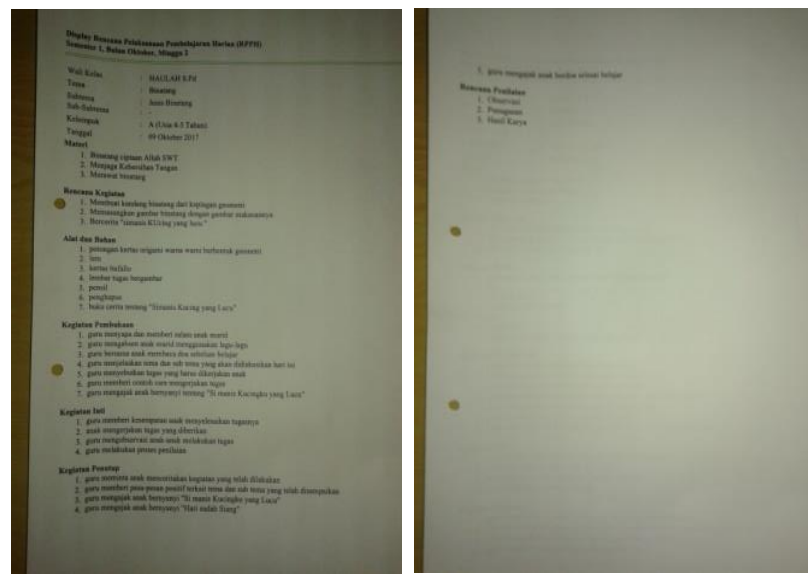

Gambar 9. Hasil RPPH Menggunakan AP3

\subsection{Pembahasan}

Berdasarkan hasil kegiatan yang telah diuraikan di atas dapat dikatakan bahwa kegiatan pengabdian kepada masyarakat dalam skim Ipteks bagi Masyarakat (IbM) ini memberikan manfaat bagi peserta pelatihan, workshop maupun seminar.

1) Kegiatan Seminar Tumbuh Kembang dan Kurikulum 2013 dan Workshop Pemanfaatan Aplikasi dalam Penyusunan Perencanaan Pembelajaran

Dari pelatihan tumbuh kembang dan kurikulum 2013, diperoleh data sebesar $83.30 \%$ guru TK mengetahui kurikulum 2013, namun hanya $20.83 \%$ guru TK yang memahami mengenai kurikulum 2013. Sebesar $91.70 \%$ mengakui bahwa mereka mengalami kesulitan dalam memahami kurikulum, dengan jumlah yang sama yaitu sebesar $91.70 \%$ guru-guru juga mengalami kesulitan dalam menerapkan kurikulum 2013.

Hal lain yang juga menjadi masalah adalah sulitnya membuat RPPH, dari 24 orang guru sebanyak $79.20 \%$ guru menyatakan bahwa tidak mudah membuat RPPH. Sementara guru-guru yang membuat RPPH, sebanyak $71.90 \%$ diantaranya membuat RPPH dengan menggunakan tulis tangan. Dari hasil angket yang diberikan kepada guru-guru TK mengenai pengetahuan, pemahaman dan penerapan kurikulum 2013 secara keseluruhan diketahui bahwa guru-guru mengalami kesulitan dalam memahami serta menerapkan kurikulum 2013. Sebagai solusi dari masalah tersebut dilakukan workshop penggunaan aplikasi yang telah disiapkan.

2) Kegiatan Seminar Parenting "Pembelajaran Calistung dan Dampaknya Bagi Tumbuh Kembang Anak Usia Dini"

Berdasarkan hasil angket diketahui pula adanya peningkatan pengetahuan dan pemahaman orangtua akan pentingnya stimulasi pada anak usia dini. Salah satunya terlihat dari adanya perubahan cara menstimulai kemampuan calistung anak. Awalnya pembelajaran calistung diajarkan orang tua kepada 
anak-anaknya dengan cara-cara yang kurang menyenangkan, dimana anak dikenalkan huruf demi huruf, angka demi angka, mengeja, menuntun tangan anak untuk membuat suatu tulisan serta membelikan buku untuk dibaca.

Setelah mengikuti seminar parenting ada perubahan dalam cara menstimulasi anak. Orangtua mengajarkan anak untuk memiliki kemampuan calistung dengan mengajaknya bermain maupun dengan bernyanyi. Selain itu juga, orangtua menyatakan akan menggunakan media konkrit sebagai alat bantu anak dalam belajar berhitung. Hal ini sesuai dengan metode pembelajaran anak di TK yang dituliskan dalam buku Panduan Pengelolaan Taman Kanak-kanak yang dikeluarkan Direktorat Pembinaan Taman Kanak-kank dan Sekolah Dasar, Departemen Pendidikan Nasional (2006), yang dua diantaranya adalah metode bernyanyi dan metode bermain. Selain itu stimulasi yang diberikan orangtua dengan memanfaatkan benda konkrit juga telah sesuai dengan prinsipprinsip pembelajaran di TK, yang salah satunya adalah menggunakan berbagai media dan sumber belajar.

\section{3) Workshop}

Dari hasil evaluasi workshop diketahui bahwa dengan aplikasi penyusunan perencanaan pembelajaran baik bentuk RPPM dan RPPH dapat dilakukan dengan mudah dan cepat dibandingkan dengan penyusunan RPPM dan RPPH secara manual atau tulis tangan maupun menggunakan komputer baik program microsoft excel ataupun program microsoft word. Selain itu aplikasi yang diajarkan juga memudahkan pengeditan data serta memungkinkan untuk menyimpan arsip dengan lebih aman.

Kemudahan yang diperoleh melalui penggunaan teknologi sesuai dengan pengertian Teknologi Informasi yaitu suatu teknologi yang digunakan untuk mengolah data, termasuk memproses, mendapatkan, menyusun, menyimpan, memanipulasi data dalam bebragai cara untuk menghasilkan informasi yang berkualitas, yaitu informasi yang relevan, akurat dan tepat waktu untuk keperluan pribadi, bisnis, pemerintadan dan merupakan informasi yang strategis untuk pengambilan keputusan. (Martin dalam Cahyana, 2015).

\section{4) Pendampingan}

Kegiatan selanjutnya setelah workshop adalah pendampingan yang bertujuan membantu guru TK dalam memanfaatkan AP3 untuk menyusun perencanaan pembelajaran. Pendampingan yang dilakukan juga sebagai bentuk evaluasi keberhasilan kegiatan pengabdian kepada masyarakat.
Pendampingan yang dilakukan berguna untuk mengetahui dengan jelas apakah guru TK memahami AP3 dan dapat memanfaatkan AP3 tersebut dalam menyusun rencana pelaksanaan pembelajaran. Pendampingan juga berguna untuk mengetahui tingkat kemampuan guru TK dalam menyusun rencana pelaksanaan pembelajaran tersebut.

\section{KESIMPULAN}

Berdasarkan hasil kegiatan yang telah dicapai, dapat disimpulkan bahwa kegiatan pengabdian kepada masyrakat dalam bentuk transfer ilmu pengetahuan dalam upaya meningkatkan kemampuan guru TK melakukan Penyusunan Perencanaan Pembelajaran dengan menggunakan Aplikasi Penyusunan Perencanaan Pembelajaran (AP3) berjalan sesuai rencana dan menunjukkan hasil sesuai dengan tujuan.

Peningkatan kemampuan guru TK dalam membuat RPPM dan RPPH dapat dilihat dari hasil kerja guru TK menggunakan AP3 serta waktu yang dibutuhkan untuk menyelesaikan penyusunan RPPM dan RPPH. (Gambar 8 dan 9) Hal tersebut sekaligus menjadi indikator keberhasilan kegiatan pengabdian kepada masyarakat yang dilakukan.

Implikasi kegiatan pengabdian bagi masyarakat dalam penggunaan AP3 sebagai alat bantu penyusunan perencanaan pembelajaran selain bermanfaat bagi guru-guru TK yang memudahkan secara proses penyusunan serta hemat dalam waktu pengerjaan, juga bermanfaat bagi kepala sekolah dan tenaga kependidikan yang lebih tinggi seperti pengawas maupun ketua IGTKI. Pihak-pihak tersebut akan dengan mudah mengetahui kinerja guru TK terkait pelaksanaan persiapan mengajar khususnya penyusunan perencanaan pembelajaran baik RPPM maupun RPPH. Kepala sekolah, pengawas dan ketua IGTKI dapat melihat hasil kerja tersebut hanya dengan menggunakan AP3, tanpa perlu mendatangi sekolah untuk melihat keberadaan berkas yang dibutuhkan.

Manfaat lain dari kegiatan pengabdian kepada masyarakat dalam pemanfaatan AP3 ini adalah berkas perangkat pembelajaran yang akan tersimpan secara aman dan dapat digunakan kapan pun diperlukan karena tersimpan dalam bentuk file. AP3 ini juga dapat disetting sesuai kebutuhan dan jangkauan pengguna. Artinya, apabila dikehendaki, guru-guru TK dimanapun berada dapat melihat perangkat pembelajaran yang dibuat oleh guru-guru TK yang lain. Sebaliknya, AP3 juga dapat dibuat untuk jangkauan dan kalangan tertentu sehingga terjaga privacy-nya. Kemudahan lain dari penggunaan AP3 ini adalah guru TK dapat menyusun perencanaan pembelajaran dimanapun berada dengan menggunakan gadget berupa HP. Sehingga tidak ada alasan bagi guru TK untuk tidak membuat RPPM dan RPPH karena sedang bepergian jauh atau sedang tidak membawa laptop. 


\section{UCAPAN TERIMA KASIH}

Ucapan terimakasih kami sampaikan kepada DRPM Ristekdikti sebagai pemberi dana kegiatan pengabdian masyarakat pada skema IbM serta Lembaga Penelitian dan Pengabdian Masyarakat Universitas Al Azhar Indonesia yang telah memberikan dukungan serta berbagai fasilitas guna memperlancar kegiatan pengabdian kepada masyarakat ini.

\section{DAFTAR PUSTAKA}

Cahyana, Raffiansyah Junisar. (2015). Fungsi dan Peran Teknologi Informasi (Aplikasi/ ) bagi Perusahaan.Kompasiana. Dilihat, 17 Agustus 2017.www.kompasianan.com/raffiansyahjc/fun gsi-dan-peranan-teknologi-informasi-aplikasibagi-perusahaan_5656f3cb159373db144f054d.

Jihad, Asep dan Haris, Abdul. (2008). Evaluasi Pembelajaran. Yogyakarta. Multi Presindo.

Majid, Abdul. (2007). Perencanaan Pembelajaran: Mengembangkan Standar Kompetensi Guru, Bandung. Rosda Karya.

Moeslichatoen. (19990. Metode Pengajaran di Taman Kanak-kanak. Jakarta: Rineka Cipta.

Peraturan Menteri Pendidikan dan Kebudayaan Republik Indonesia (Permendikbud RI) No. 146 Tahun 2014.

Peraturan Menteri Pendidikan dan Kebudayaan Republik Indonesia (Permendikbud RI) No. 137 Tahun 2014.

Permendikbud No 81A tahun 2013 tentang implementasi Kurikulum Pedoman Umum Pembelajaran

Ramdhan, Taufik. (2012). Pentingnya Teknologi Ilmu Komputer. Diakses 17 Agustus 2017. http://www.google.com/amp/s/tufikramdhan40 1.wordpress.com/2012/10/10/pentingnyateknologi-ilmu-komputer/amp/.

. (2015). Penyusunan Rencana Pelaksanaan Pembelajaran Pendidikan Anak Usia Dini. Kementerian Pendidikan dan Kebudayaan. Direktorat Jenderal Pendidikan Anak Usia Dini dan Pendidikan Masyarakat. Direktorat Pembinaan Pendidikan Anak Usia Dini. Jakarta 